Multidisciplinary SCIENTIFIC JOURNAL OF MARITIME RESEARCH

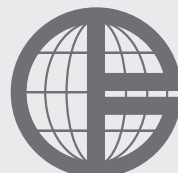

University of Rijeka

Faculty of Maritime

Studies Rijeka
Multidisciplinarni

znanstveni časopis

POMORSTVO

https://doi.org/10.31217/p.32.2.8

\title{
Research on the Energy Efficiency Indicators of Transport Diesel Engines under Transient Operation Conditions
}

\author{
Sergejus Lebedevas ${ }^{1}$, Paulius Rapalis ${ }^{1}$, Rima Mickevicienè ${ }^{2}$ \\ ${ }^{1}$ Faculty of Marine Engineering, Marine Engineering department, Klaipeda University, Bijūnų Str. 17 Klaipeda Lithuania, e-mail: Sergejus.Lebedevas@ \\ ku.lt; e-mail: Paulius.Rapalis@ku.lt \\ ${ }^{2}$ Faculty of Marine Engineering, Marine Engineering department, Klaipeda University, Bijunu Str. 17 Klaipeda Lithuania, e-mail: Rima.Mickeviciene@ku.lt
}

\section{ABSTRACT}

In this study, we have investigated the efficiency of transport diesel engines CAT3512B-HD in transient braking and acceleration modes in $2 \mathrm{M} 62 \mathrm{M}$ locomotives. A comparative analysis of the diesel engine performance has been performed at speeds of power increase and braking ranging from $4-5 \mathrm{~kW} / \mathrm{s}$ to $17-18 \mathrm{~kW} / \mathrm{s}$. A decrease in the fuel economy occurred, and the main reason for it (compared with the steady-state operating condition at $\mathrm{q}_{\mathrm{cycl}}=\mathrm{idem}$ ) has been found to be the deterioration of the mechanical efficiency coefficient due to the loss of the additional equipment kinetic energy of the engine. The efficiency decreased by $3-3.5 \%$ under power increase operations and by $10-14 \%$ in the braking modes. The original methodology for the evaluation of the diesel engine parameters registered by the engine control units (ECU) in the engine operating conditions, mathematical modelling application AVL BOOST, and analytical summaries in artificial neural networks (ANNs) have been used. The errors in the obtained results have been $5-8 \%$ at a determination coefficient of $0.97-0.99$.

\section{ARTICLE INFO}

Original scientific paper Received 21 June 2018

Accepted 22 November 2018

Key words:

Diesel engine

Transient operation

Energy indicators

Mathematical modelling

Artificial neural networks

\section{Nomenclature}

$\eta_{e}-$ effective efficiency coefficient

$\eta_{I}-$ indicated efficiency coefficient

$\eta_{m}-$ mechanical efficiency coefficient

$\eta_{e l}-$ electric coefficient of efficiency

$\varphi_{z}$ - heat release duration

$a_{1}, a_{2}, a_{3^{\prime}} a_{4}$ - constant coefficients

$\mathrm{m}$ - Vibe formfactor

$n$ - engine speed, min $^{-1}$

$n_{f}$ - Engine speed measured, min $^{-1}$

$n_{n}$ - engine speed as a function of the fuel injection portion, min $^{-1}$

$P_{e f}-$ effective power of the diesel engine, $\mathrm{MPa}$

$P_{e l}$ - electric power of the diesel generator, $k W$

$P_{k}$ - charge air pressure, bar

$P_{k 0}$ - charge air pressure at nominal power, bar

$P_{k i}$ - charge air pressure at load duty I, bar

$P_{m e}$ - average effective pressure, $\mathrm{MPa}$

$q_{\text {cikl }}$ - fuel injection portion, $g / c y c l e$
$T_{0}$ - charge air temperature at nominal power, $K$

$T_{i}$ - charge air temperature at load duty I, $K$

$T_{k}$ - charge air temperature, $K$

$\alpha$ - excess air coefficient in the cylinder

$\beta$ - air-use coefficient

$\varepsilon-$ compression coefficient in the cylinder

$\eta_{\text {ef }}$ - effective coefficient of efficiency calculated from the fuel consumption

$\eta_{e n}$ - effective coefficient of efficiency calculated as a function of the excess air ratio and fuel portion

$\eta_{i f}$ - indicated coefficient of efficiency calculated as a function of the excess air ratio

$\eta_{m n}$ - mechanical efficiency coefficient calculated as a function of the excess air ratio and fuel portion

$\lambda$ - pressure increase ratio during compression

$\varphi_{\tau i}$ - induction period in the i-load duty, ${ }^{\circ}$ crankshaft deflection angle

$\varphi_{\text {tio }}$ - induction period in the nominal load duty, ${ }^{\circ}$ crankshaft deflection angle 


\section{Introduction}

The energy characteristics and optimization research of a diesel engine (DE) during operation are some of the most effective approaches for improving the efficiency, reliability, and ecological indicators. Numerous studies have been carried out in the area of DEs via experimental and mathematical modelling research, with an increased attention to transient operation modes $[2,11,22,25,34,35$, 36].

The transport DE operation often results in transient operation modes which are related to the energy efficiency deterioration $[22,36]$. One of the reasons for the deterioration is that because of the inertia characteristics of the of the DE turbocharger unit, the filling of the cylinder with air is delayed as a function of the dynamic parameters of the fuel cyclical portion change. The filling is either insufficient during the fuel portion increase or excessive during the fuel portion reduction. Both cases, i.e. lack or excess of air, have a detrimental effect on the engine efficiency.

Other factors affecting the mechanical performance coefficient and energy indicators are the inertia characteristics of moving elements of the engine [30]. This is particularly characteristic for heavy transport engines (such as ships and locomotive applications, where the engines are coupled with power generators, reduction gearboxes, and auxiliary devices) [40, 46].

The current diesel engine control units (ECUs) are capable, to a large extent, of mitigating the negative effects of a transient operation. $[3,26]$. However, the conditions of the operation of the diesel equipment, even of the same function and type, vary tremendously, and the regulating parameters of the ECU are determined according to the defined DE operation function, which may not be optimal for different operation conditions and equipment. For example, the railway profile or sea conditions can significantly vary depending on the geographical location. In locomotive applications, the spectrum of the engine load modes and dynamic parameters depends on the profile of the freight transportation lines, traffic restrictions, gross weight of the locomotives, and locomotive control system $[19,24]$. This is illustrated by the example in Figure 1. Figure 1a shows the DE CAT3512B-HD operation load spectrum in a $2 \mathrm{M} 62 \mathrm{M}$ diesel locomotive, and Figure $1 \mathrm{~b}$ presents the histogram of the 2M62M operation in different Joint Stock Company "Lithuanian Railways" railroad lines.

Different operation modes determine the fuel consumption per work unit (t.km) and different energy use efficiency indicators (evaluated by the effective coefficient of efficiency $\left(\eta_{\mathrm{e}}\right)$ or electric coefficient of efficiency $\left(\eta_{\mathrm{e}}\right)$. Hence, the possibility of determining and controlling the efficiency indicators of the DE energy use under operational conditions can be viewed as an effective direction for the improvement of the DE equipment efficiency. This was also analysed in the authors' earlier work [19].

The operation of DEs with a "Common Rail" fuel supply system under transient operation modes has, in different aspects, been researched and simulated by Rakopoulos, Nikzadfar, and others [34, 36, 30]. Giakoumis [7] examined the effect of the DE transient operation modes on the nitrogen oxide emissions. The methodology used in this research has been based on the analysis of the engine operation under steady-state and transient modes. During the experiment, based on this methodology, three/fourdegree polynomials have been composed, describing the
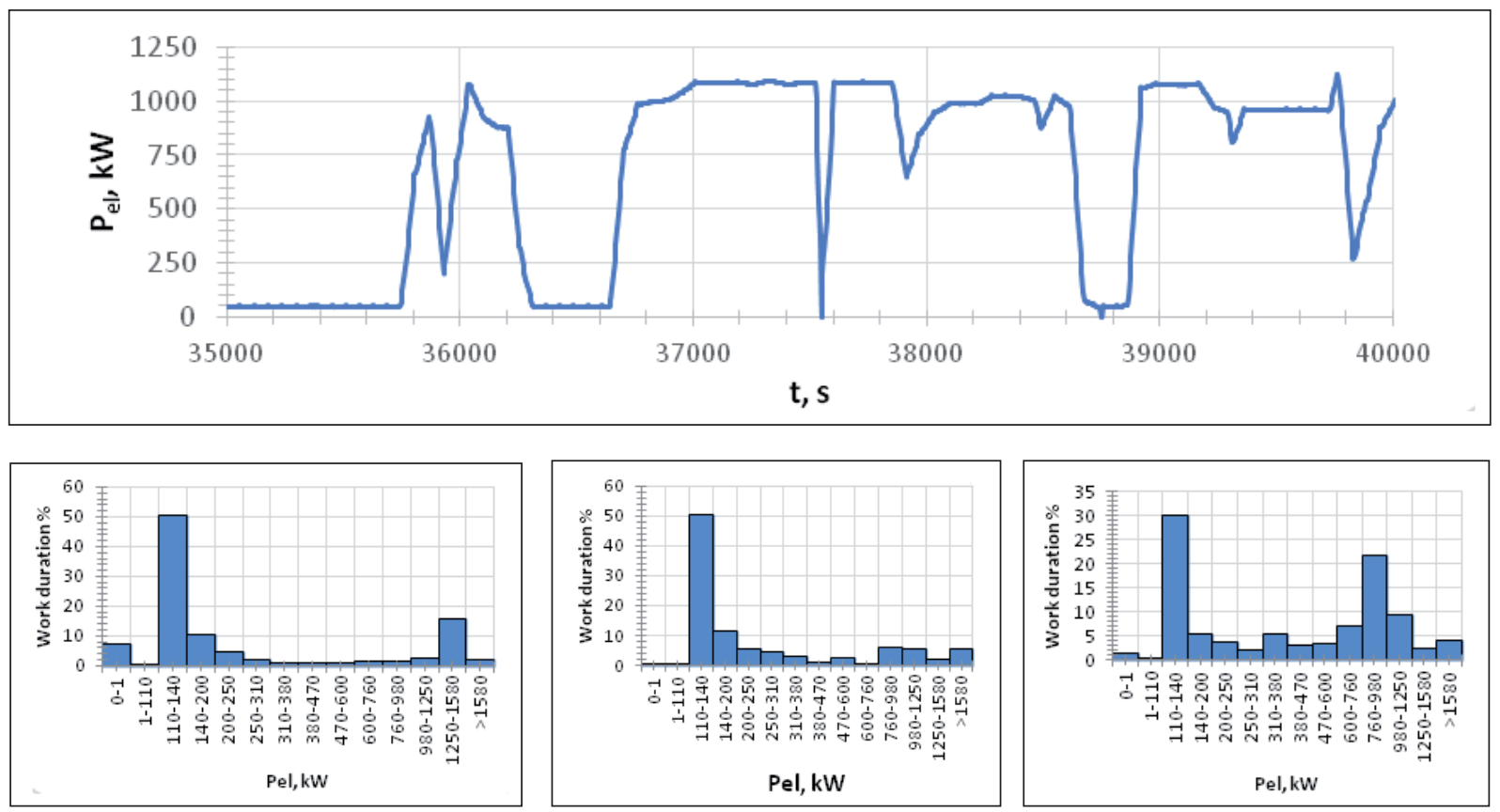

Fig. 1 Structure of the Cycle of an Operational Load of a Freight Locomotive Diesel Engine:

(b) CAT3512B-HD DE in different lines; (a) CAT3512B-HD DE line Vaidotai-Radviliškis 
dependence of the DE operational and ecologic parameters on the speed and torque. Following this, the correction coefficients have been established for the evaluation of the changes during transient operation modes. A similar approach has been adopted by Nüescha for the optimization of a hybrid diesel-electric car load cycle to reduce the emissions of NOx and improve the efficiency [31]. The research on the effect of the more powerful DE machinery in the transient modes has been performed by Hansson and Lindgren, who have analysed the fuel overconsumption in the agricultural machinery transient modes [9, 23]. Studies of the DE transient and steady-state operation mathematical models have been carried out using advanced mathematical modelling tool AVL BOOST programme [8]. There is, however, a significant lack of published research on the transient operation of non-road engines, particularly in the rail and shipping applications. This study provides additional insights into the transient operation of heavy DEs and the analysis methods which can be implemented on different types of heavy transport DEs in operation.

\section{Materials and Methods}

\subsection{Research Methodology}

The research object has been the CAT3512B-HD series DE installed in 2M62M locomotives. The technical parameters of the DEs are listed in Table 1.

The research data have been the engine parameters registered by the ECU in CAT3512B-HD during their operation. The modes of the transient acceleration and power reduction were analysed. The electric power of the diesel locomotive power unit has been examined together with

Table1 Technical Parameters of CAT3512B-HD Des [38]

\begin{tabular}{|l|c|}
\hline \multicolumn{1}{|c|}{ Parameter } & CAT3512B-HD \\
\hline Power (kW) & 1700 \\
\hline Speed (min-1) & 1800 \\
\hline Number of cylinders & 12 \\
\hline Cylinder diameter (mm) & 170 \\
\hline Piston stroke (mm) & 215 \\
\hline Fuel injection & System of “Common Rail” type \\
\hline
\end{tabular}

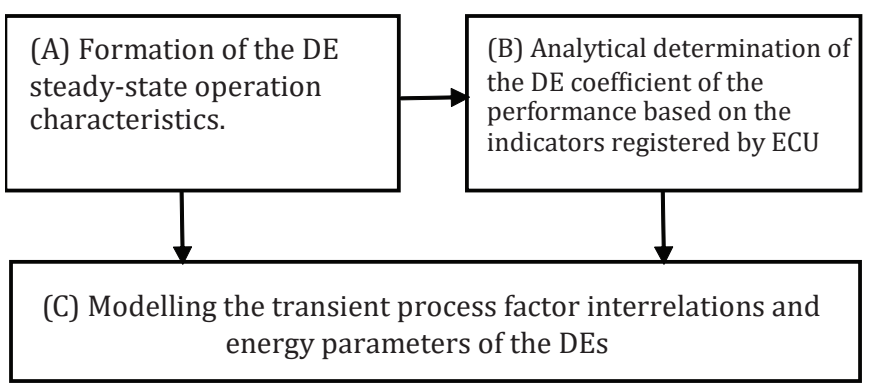

Fig. 2 Structural Block Form of the DE Transient Operation Mode Research Methodology the installed auxiliary equipment. Although the research has been performed on the CAT3512B-HD engine in freight diesel locomotive $2 \mathrm{M} 62 \mathrm{M}$, the results also correlated well with the data of other locomotive DEs in the SC "Lithuanian Railway" network railway lines [21]. On this basis, it can be stated that the evaluation and suggestions provided below are suitable for the entire fleet of freight diesel locomotives.

As it was mentioned, CAT3512B-HD DEs are equipped with ECUs with a wide range of registered parameters. The accuracy of the major parameter measurement is characterized by a systematic error not exceeding $1-1.5 \%$ [4]. The methods for the ECU data acquisition and preparation for the analysis have been presented in detail in an earlier work of the author [20].

The realization of the engine transient operation research methodology includes the interrelated technological blocs as presented in Figure 2. For the realization of " $\mathrm{C}$ " and " $\mathrm{A}$ " technologies, a combination of the engine work process modelling and artificial neural network solutions have been used.

\subsection{Mathematic Modelling}

In the research on the transient modes, steady-state operation tests have been also performed on a rheostat and an improved more accurate (in comparison with an earlier work [20] of the author) mathematic model of the CAT3512B-HD engine has been developed in the AVL BOOST programme. A single-zone Vibe model has been used for the combustion evaluation [43]. The changes in the basic model parameters under different load conditions have been described by the Woschni analytical formulas $[27,45]$. The adequacy of the model has been confirmed by the error between the model and experiment, not exceeding $2-4 \%$. The results and model are presented in Figure 3 (a-c: results comparison; d: diagram of the model in the AVL Boost application)

The CAT3512B-HD work process parameters for the modelling have been expanded, including the modelling of the indicator coefficient performance over a wide range of speeds and loads. The results of the modelling have been approximated by the software of artificial neural networks.

Instead of determining the main influencing physical coefficients (heat transfer and heat release), important criteria relative to the combustion process have been selected for the evaluation of the work process changes, i.e. excess air ratio $(\alpha)$ and cyclic injection portion $\left(\mathrm{q}_{\text {cycl }}\right)$.

\subsection{Determination of the Energy Use Efficiency Indicators of a Diesel Engine}

The ECUs are mostly unable to register the parameters of high-speed processes in the cylinders [3]. Concurrently, the most informative parameters of the heavy DE working process are the integral values of the indicative and mechanical coefficients of efficiency. Based on the findings of 

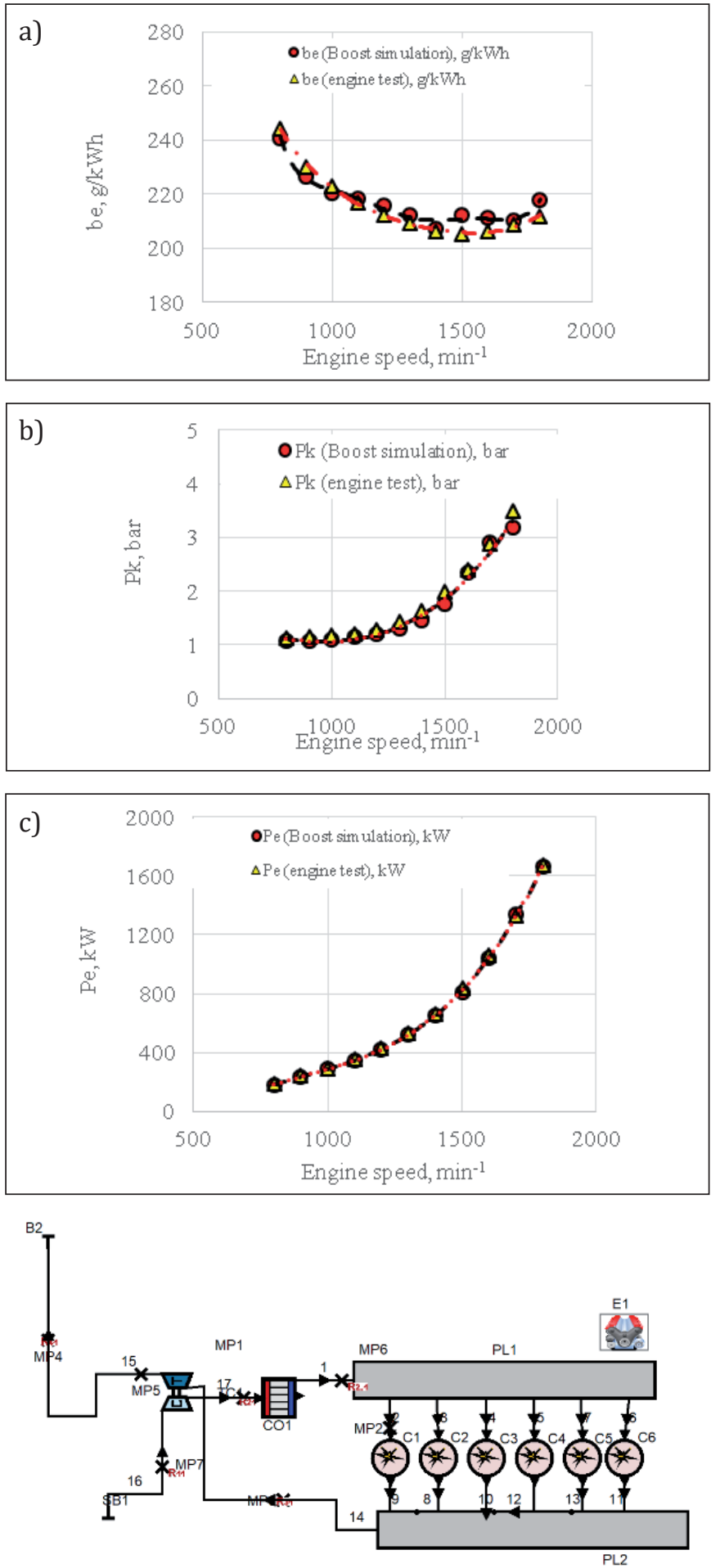

Fig. 3 Comparison of the Steady-state Boost Simulation and Rheostat Engine Tests Performed at the SC "Lithuanian Railway"

other researchers $[32,28]$, it can be stated that the excess air ratio and cyclical fuel injection portion can be used for evaluating the DE dynamic characteristics and solving the majority of other practical tasks related to the improvement of the operation indicators of the engine [32, 28]. From the classical theory of an internal combustion engine, the effective coefficient of the performance has been determined from the indicator and mechanical coefficients of the performance. Parameter $\eta_{e}$ can be determined immediately according to the consumption of the fuel and ECU-registered power (or torque and speed).

In the operation research, it is difficult to determine the mechanical coefficient of the performance. Therefore, in the equation for the indicated system, the coefficient of the performance is used instead of the mechanical coefficient of the performance.

Depending on the air unit in the cylinder and fuel injection process, the value of the coefficient of the performance changes numerous times from one cycle to another during the transition. Simultaneously, for the determination of the indicator coefficient of the performance in the transient process, the coefficients have been used with the same indicator, i.e. the coefficient of the performance in the steady-state modes and analytical dependence may be used.

In the transient modes, the task of establishing the indicator coefficient of performance $\eta_{i}$ includes two main components:

1. Recreation of similar to transient state conditions, determining the $\eta_{i}$ graphic or analytical dependence on $\alpha$ and $\mathrm{q}_{\mathrm{cyc}}$;

2. Based on the DE parameters registered by the ECU and data of the first component, determine the values of transient mode $\eta_{i}$ analytically.

\subsection{Key Factors Influencing the Working Process of the Energy Efficiency of a Diesel Engine}

For studying the DE energy parameters and their optimization, analytical methods have been used for a long time for the indicated efficiency coefficient determination from the working process parameters (depending on the coefficient with excess air coefficient $(\alpha)$ ). The interconnections between the energy and ecological indicators with the excess air ratio have a significant relevance in the modern theory and practice of internal combustion engines. Research in this direction involves efficiently solving the optimal use of alternative fuels in DEs [42, 13, 29, 44]. Basically, the excess air coefficient is used as one of the criteria for determining the distinctiveness of the indicator process. The heat release characteristics have been obtained by $\eta_{i}$ optimizing the composition of the biofuel mixes to improve the complex energy and ecological parameters. The DE research in classical literature uses highly extensive functions related to the rational organization of theoretical and indicative work processes for the use of the parameter of air/fuel or excess air ratio [5, 28, 10, 33, 41]. One of the first studies has been performed to highlight the interrelation between $\eta_{i}=(\alpha)$. It has been conducted with regard to the wide range of high-speed DEs [33].

This research has examined the effect of the excess air coefficient on $\eta_{i^{*}}$. According to the author, the key factors describing the value of the performance coefficient of the working process are $\alpha$ and $\lambda$ (where $\lambda$ is the de- 
gree of pressure increase, calculated as the ratio of the maximum cycle pressure and the pressure at the top dead centre). However, when $\alpha=1.2-2.4$, in the range, the key effect on $\eta_{i}$ is achieved by the excess air coefficient $(\alpha)$. Its increase in the range ensures more favourable conditions for the fuel combustion in the cylinder of the DE. The positive effect on $\eta_{i}$ significantly decreases when the excess air coefficient reaches the range $\alpha>2.4$ and it even exhibits a negative effect on $\eta_{i}$ [41]. The main conclusions of the work have been confirmed by [33] and graphic dependence $\eta_{i}=f(\alpha)$, adequately approximated by the equation $\eta_{i}=\alpha^{-\beta}$, where $\beta$ is the air-use coefficient, opposite to parameter $\alpha$. The working solutions used by Prof. Ivanchenko [12], operating $\eta_{\mathrm{i}}$ for the indication of parameters $\alpha, \lambda$, $\varepsilon$, and $P_{k}$, very well correlate with the previously reviewed works. One of the authors of this publication, has productively solved the rational parameter selection for the perspective DE BMD and modernization of series $6,-8$ MTU396TC4 by applying this methodology $[17,18$, 16]. Overall, by evaluating the field of the research, one can state that

- These methods, along with direct experiments, are effective for the optimization of the DE construction and regulation parameters when the dependence of the working process characteristics does not change. Furthermore, based on the construction and regulation parameters, they are analogous to the analysed ones.

- Even though $\alpha$ is one of the major parameters exerting a key effect on the indicator coefficient of the efficiency influencing the working process, establishing the engine efficiency parameters only on this basis can be complex.

Therefore, the majority of the experimental DE research certifies that under the conditions of $\alpha=$ idem, the value of $\eta_{i}$ largely depends on the formation of the fuel/ air mixtures and combustion process factors. The characteristics of the heat released in a DE cylinder depend on these factors, which in turn form the energy and ecology reliability indicators $[28 ; 16]$. Concerning the dynamics of the heat released, Woshni has proposed a widely used relation for the heat release parameter evaluation equation [45]:

$\frac{m_{i}}{m_{0}}=\left(\frac{\varphi_{\tau i 0}}{\varphi_{\tau i}}\right)^{A_{2}} \cdot \frac{P_{k i} \cdot T_{k 0}}{P_{k 0} \cdot T_{k i}} \cdot\left(\frac{n_{0}}{n_{i}}\right)^{A_{1}} \ldots, \ldots \frac{\varphi_{z i}}{\varphi_{z 0}}=\left(\frac{\alpha_{0}}{\alpha_{i}}\right)^{A_{4}} \cdot\left(\frac{n_{i}}{n_{0}}\right)^{A_{4}}$

where $A_{1^{\prime}}, A_{2^{\prime}} A_{3^{\prime}}$ and $A_{4}$ - constant coefficients; $T_{0}$ and $T_{i}$ - respectively are the $\mathrm{T}_{\mathrm{K}}[\mathrm{K}]$ at nominal power and during load duty $i ; P_{k 0}$ and $\mathrm{P}_{\mathrm{ki}}-$ respectively are the $P_{K}[\mathrm{~Pa}]$ at nominal power and during load duty $i$; $\mathrm{m}$ and $\varphi_{z}$ are the heat release characteristics, expressed in the terms of the mathematic model created in Vibe (43), formfactor, and heat release duration; $\varphi_{\tau i}$ and $\varphi_{\tau i 0}$ - respectively, are the induction period $\left(^{\circ}\right.$ crankshaft deflection angle) in the nominal and $i$-load duty directions. For the performed analysis, the methodology of $m$ and $\varphi_{z}$ parameter indication is used successfully in modelling the heat processes, both for the wide range of fuels and transient mode of operation [27,37].
The designed methodology considering the relatively limited amount of the data registered in the ECU, evaluates the energy efficiency parameters.

\section{Results}

\subsection{Establishment of the Indicator Coefficient of the Performance according to the Parameters Registered in the Engine Control Unit}

According to the evaluated results, the use of parameter $\alpha$ as one of key factors determining $\eta_{i}$ is clear.

The choice of the function for the locomotive DE generates favourable conditions for approving this methodology because the operation characteristics of the diesel locomotive induces certain transient speeds and load operation modes. However, the graphic dependence, $\eta_{i}=f(\alpha)$, is ambiguous in the average and high-load range of the DE (see Fig. 4).
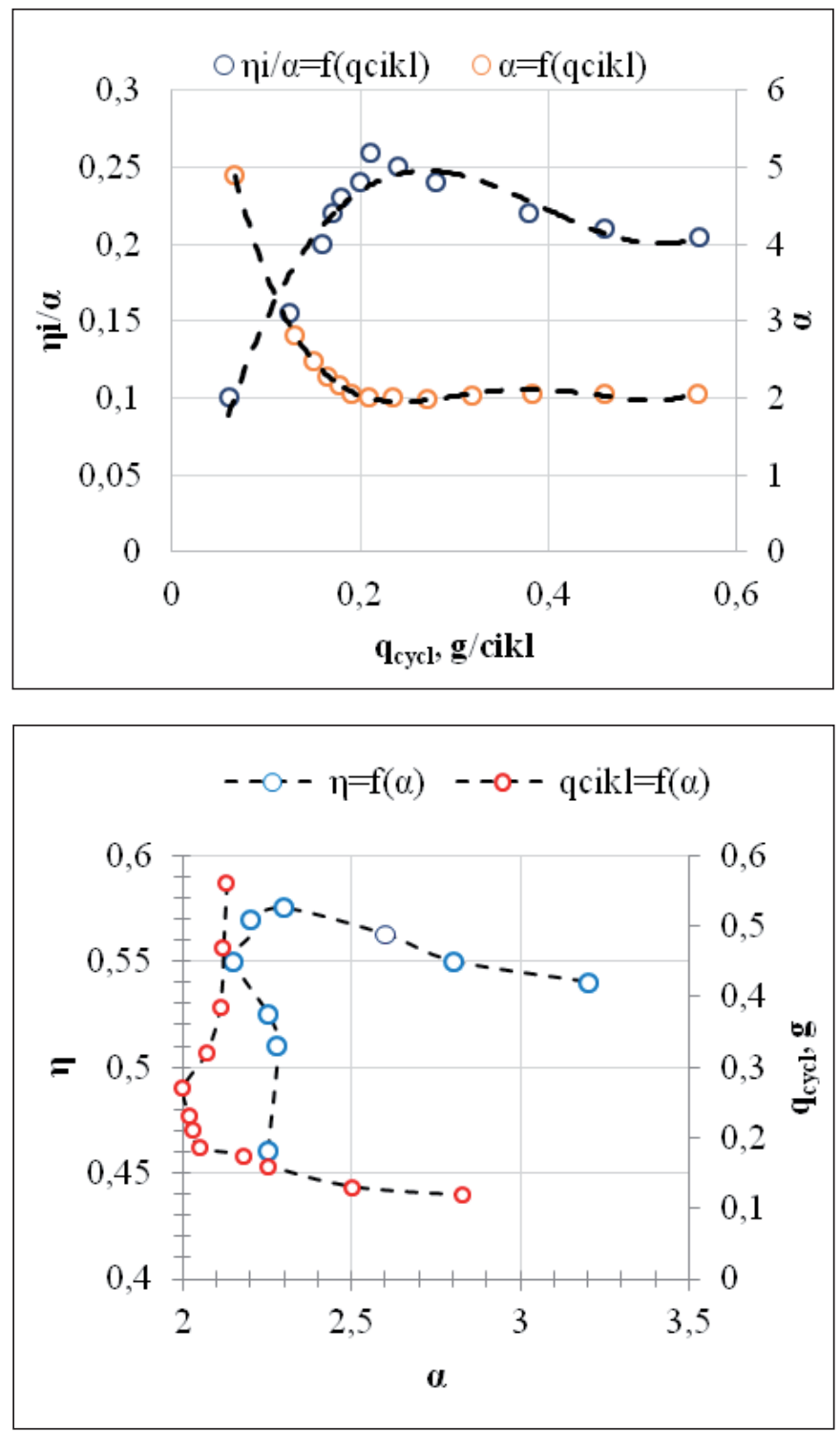

Fig. 4 Dependence of the Indicator Coefficient of the Performance under the Conditions of the DE Working Process Implementation 


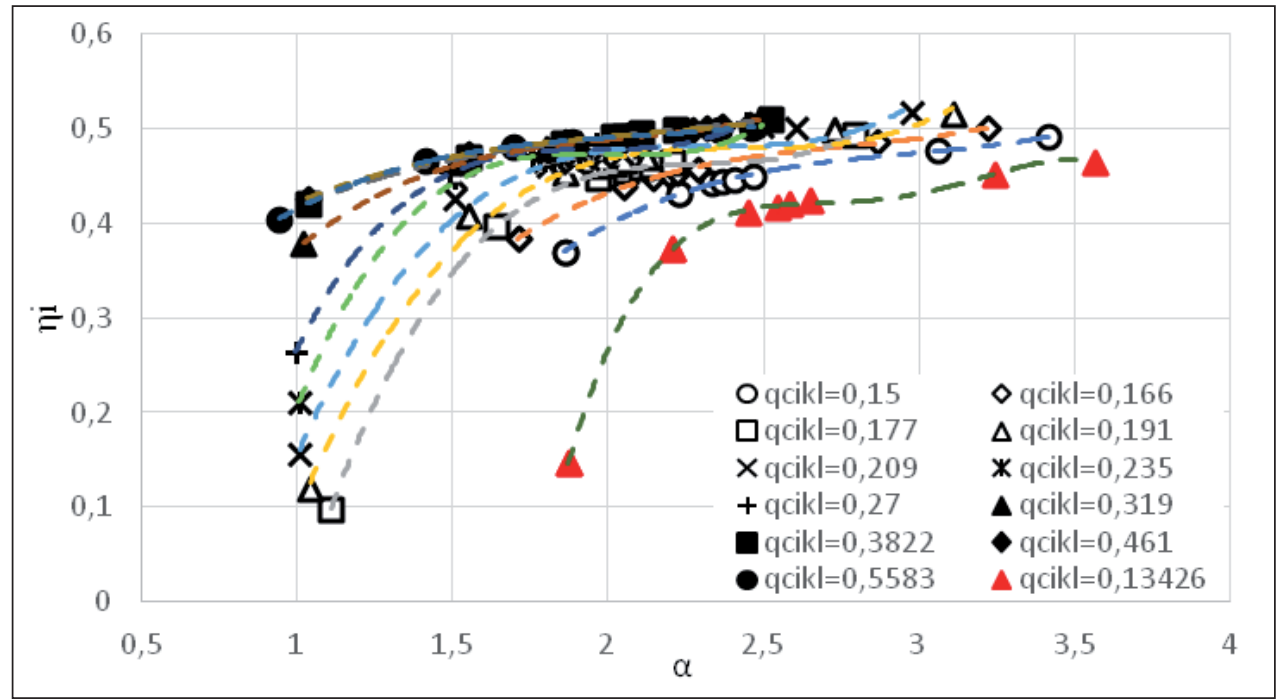

Fig. 5 Two-dimensional Form $\eta_{i}=f\left(\alpha, q_{c y c l}\right)$ Dependence, Obtained by Modelling the Process of the DE Working Process in BOOST AVL

In the range, $\alpha=2-2.5$, with identical $\alpha$ values, $\eta_{i}$ changes in the range from $0.46-0.57$. It is evident that when evaluating in the range of $\mathrm{P}_{\mathrm{me}}$, the change in the $\eta_{i}$ size together with $\alpha$ parameter have a significant effect on the distinctiveness of the working process or the characteristics of the heat release. The research has showed that the key effect of $m_{i}$ is related to the change in the heat release duration $\left(\varphi_{z}\right)$, so that the influence of the characteristics of formfactor $m$ on $\eta_{\mathrm{i}}$ is much smaller $[5,14,15,16,28,39]$. As the research has suggested, the increase in the $\varphi_{z}$ parameter with an increase in the engine load or cyclical portion of the fuel, reduces the energy indicators of the DE and consequently $\eta_{i}$. Hence, in the research, $\eta_{i}$ is associated with influencing factors $\eta_{i}=f(\alpha$, $q_{c y c l}$. In this context, $q_{c y c l}$ is evaluated as a parameter proportionate to $\varphi_{z}$. Fig. 3 shows the dependence of the parameters of the excess air coefficient $\alpha$ and the relative dependence used in internal combustion engines in practice $[6,28]$. Relative $\eta_{i} / \alpha$ graphic dependence on, has been determined.
Unlike the $\eta_{i}=f(\alpha)$ dependence (see Fig. 3), an unambiguous $\eta_{i / \alpha}=f\left(q_{c i k l}\right)$ dependence has been found. The maximum of $\eta_{i / \alpha}=f\left(q_{\text {cikk }}\right)$ dependence in the range, $\alpha$ $=2.5-2.6$ correlates well with the results of the previous research $[33,39]$.

The results reveal that for the given set of DE and parameter settings, under the operation conditions, the dependence $\eta_{i / \alpha}=f\left(q_{c y c}\right)$ or its modified forms may be used for the determination of $\eta_{i}$ in the steady-state modes. Under the real operation conditions, working in the transient mode with $q_{c y c l}=$ idem $\alpha$ value may change in the wide range. Hence, it is essential to have a data array of $\eta_{i}=f\left(\alpha, q_{c y c l}\right)$ with fixed values of $q_{c y c l}$ (in the range of DE characteristics). $\eta_{i}$ is to be determined over a wide range of $\alpha$ parameter change to smaller and larger values from the steady-state mode with characteristic $\alpha$ values. To this end, BOOST AVL programme [1] and DE CAT3512B-HD working process mathematical model has been used. The

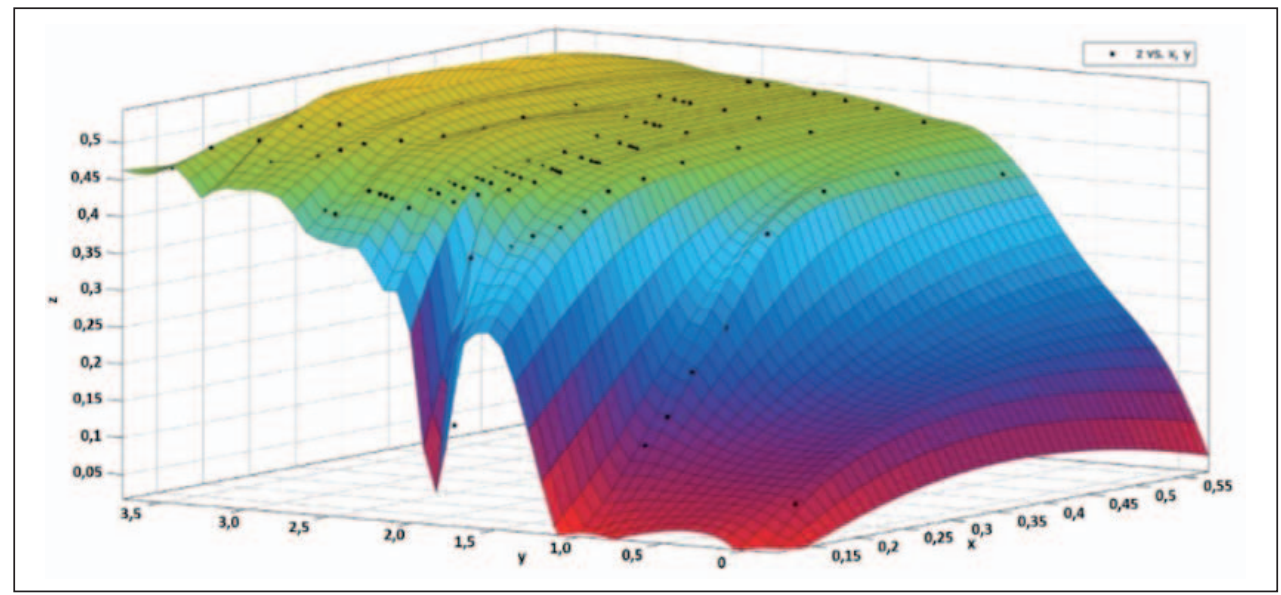

Fig. 6 Three-dimensional Form $\eta_{i}=f\left(\alpha, q_{c y c l}\right)$ Dependence Made by Modelling the Working Process of the DE by BOOST AVL (here: $\left.\mathrm{x}-q_{c y c l} \mathrm{z}-\eta_{i} ; \mathrm{y}-\alpha\right)$ 
modelling results are presented in two- and three-dimensional forms in Fig. 5 and 6, respectively.

The surface of $\eta_{i}=f\left(\alpha, q_{c y c}\right)$ has been interpolated by using artificial neural networks. The adequacy of the results is confirmed by the value of the determination coefficient, $\mathrm{R}^{2}$ $=0.956$ (see Fig. 7).

The adequacy of the modelling results is confirmed by comparing the results with the data of the rheostatic test. In the range of the $q_{c y c l}$ change researched, a conformity of 1-1.5\% difference between the mathematic modelling and experiment results has been achieved.

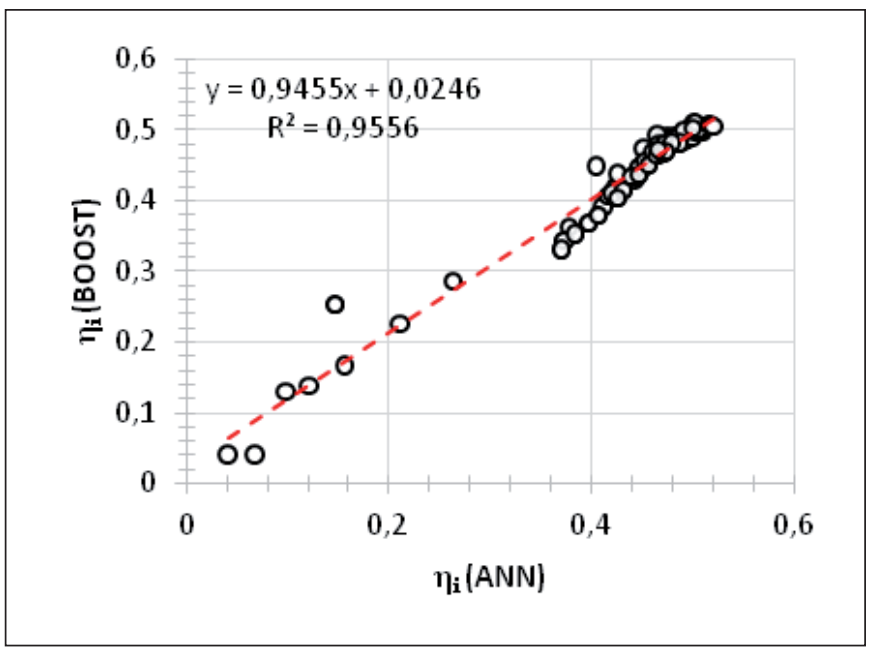

Fig. 7 Comparison of the Indicator Coefficient of the Performance from ANN $\left(\eta_{i}(\right.$ ANN $\left.)\right)$ and AVL BOOST $\left(\eta_{i}(\right.$ BOOST $\left.)\right)$

\subsection{Research on the Parameters of Energy Efficiency}

The methodology for determining the energy efficiency indicator under the operation conditions is adapted to the CAT3512B-HD series locomotive DEs. The transient processes having different intensities for the acceleration and deceleration have been performed.

The obtained results have confirmed the adequacy of the methodology. The proposed practical nature has been formed to improve the operation energy indicators of the DEs.

\subsubsection{Transient Operation Modes of Slow Acceleration}

In the course of the research, the data for differently accelerated modes from 4-5 kW/s to $17-1-8 \mathrm{~kW} / \mathrm{s}$ have been extracted and systematized to obtain a summary of the results. Fig. 8 presents the results of two acceleration operating parameters consisting of two different stages of the intensity: in the first time section 440-495 s, the parameter $\left(\mathrm{dP}_{\mathrm{ef}} / \mathrm{dt}\right)$ on an average is $15.5 \mathrm{~kW} / \mathrm{s}$ and in the section, range of 495-550 three times smaller $4.9 \mathrm{~kW} / \mathrm{s}$. Respectively, the $\mathrm{q}_{\text {cycl }}$ average change of the speed in the sections is $0.0036 \mathrm{~g} / \mathrm{s}$ and $0.0018 \mathrm{~g} / \mathrm{s}$.

In the intensive acceleration section (440-495 s), real rotation $\mathrm{n}_{\mathrm{f}}$ and power $\mathrm{P}_{\mathrm{ef}}$ of the $\mathrm{DE}$ are significant-
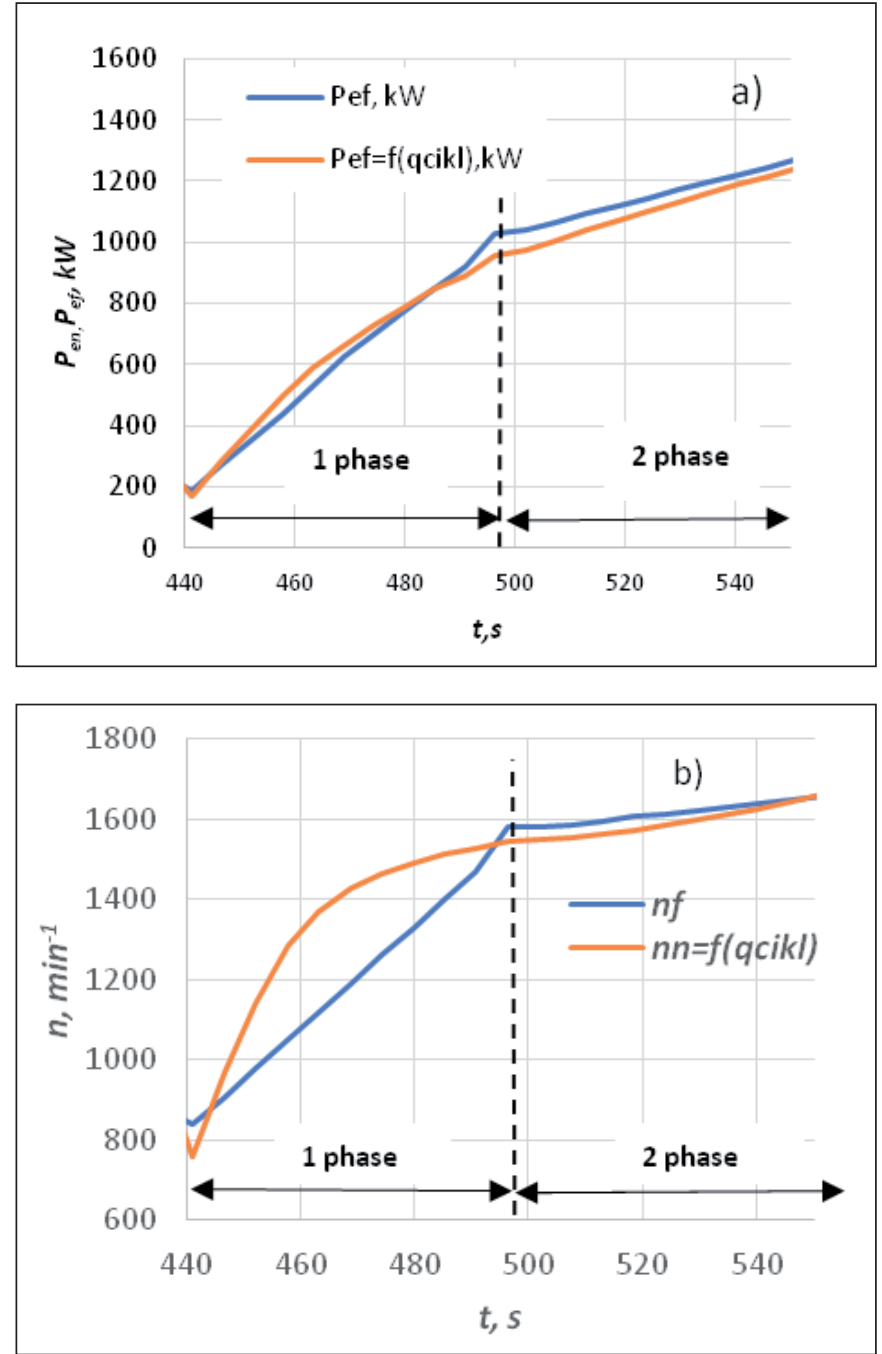

Fig. 8 Change in the Parameters of CAT3512B-HD DE Operation Mode in a Slow Acceleration Process

ly lower than in the steady-state modes (at $q_{c y c l}=$ idem); the decrease is $\sim 250 \mathrm{~min}^{-1}$ and $\mathrm{Pe} \sim 50 \mathrm{~kW}$, respectively. However, on the other side of the run-up mode, a slightly higher speed (20-30 $\left.\mathrm{min}^{-1}\right)$ and over speed (20-25 kW) are available compared with the steady-state modes.

In the first phase of the transient mode, an additional kinetic mechanical energy, which increases the DE mechanical losses, has been used for accelerating the DE with the ever-increasing acceleration. At the end of the first phase of the acceleration, with the decrease in the acceleration of the rotating units to negative values, the accumulated kinetic energy has resulted in a higher real speed $\mathrm{n}_{\mathrm{f}}$ compared to the transient process (8b).

For the confirmation of this hypothesis, using the developed methodology, the changes in the indicator $\eta_{i}$ and mechanical $\eta_{m}$ efficiency coefficients in the acceleration operation have been evaluated. The data presented in Figure 8a present one of the main parameters that determines $\eta_{\mathrm{i}}$ of the working process - the excess air coefficient $(\alpha)$ in the range of 5-2.1 units and $P_{k}$ is 2.2-2.8 bar, respectively. Accordingly, the DE cylinder air supply parameters 
do not exceed the level when the negative effect on $\eta_{\mathrm{i}}$ (see Fig. 8b) is noted (see Fig. 5 and Fig. 6) throughout the $\mathrm{q}_{\mathrm{cycl}}$ change range. At the end of the transient mode, the engine load increases. The effect of the transient operation $\alpha_{\mathrm{f}}$ is not significant; the differences $\left(\alpha_{\mathrm{f}}-\alpha_{\mathrm{n}}\right)$ on an average do not exceed 0.5-1 units. This implies that the balance of the engine cylinder air charge and cyclic fuel portion is no longer affected during the slow-speed transient operation. Fig $9 \mathrm{c}$ shows the relative (compared to the steady-state modes) DE efficiency in the transition mode: $\eta_{\mathrm{ef}} / \eta_{\mathrm{en}} \eta_{\mathrm{if}} / \eta_{\mathrm{mn}}$
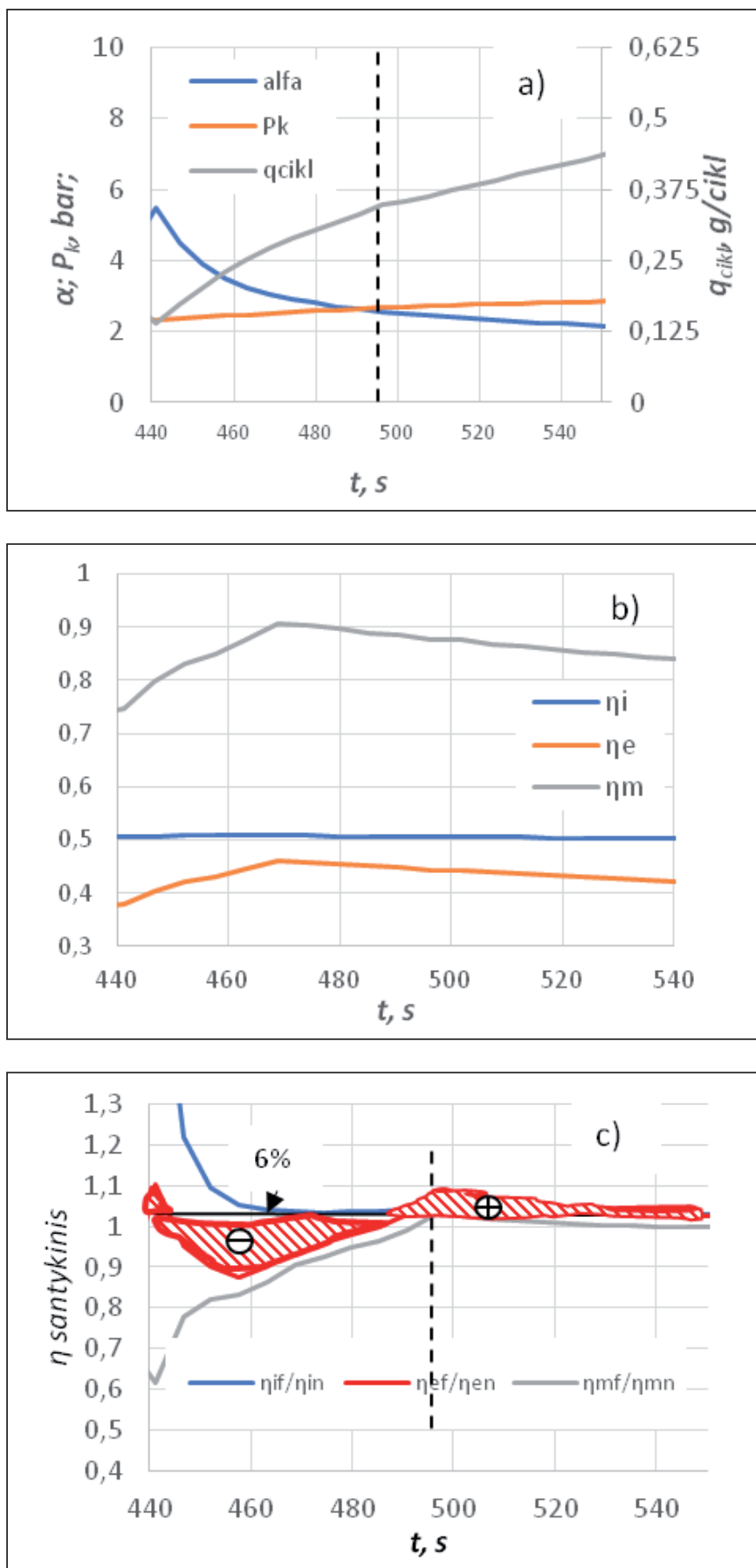

Fig. 9 Acceleration Transient Mode: a - Relative Efficiency Coefficient; $\mathrm{b}-\mathrm{P}_{\mathrm{k}^{\prime}}, \alpha$ and $\mathrm{q}_{\mathrm{cikl}} ; \mathrm{c}-$ Efficiency Coefficients Change
The relative changes in the efficiency coefficients have been compared with the steady-state modes $\eta_{\mathrm{if}} / \eta_{\mathrm{in}} ; \eta_{\mathrm{ef}} / \eta_{\mathrm{en}}$; $\eta_{\mathrm{mf}} / \eta_{\mathrm{mn}}$ in Fig. 9c. Based on the data presented in the figure, it can be concluded that the main changes in the energy efficiency indicators are determined by the changes in the mechanical efficiency coefficient in the analysed transient operation. In the transient mode, the maximum instantaneous decrease in $\eta_{\text {en }}$ values is $12 \%$ and the average value for the total transient operation is $6 \%$. According to the estimates, the fuel consumption of the locomotive engine in the transient operating modes is larger by $80 \%$ [21]. In the second acceleration phase (495-550 s), the "accumulated" kinetic energy of the engines rotational motions has increased $\eta_{m}$ by $2 \%$ on an average. In the result of the whole transient regime, the energy loss, in relation to the steadystate operating modes, is $\sim 3 \div 3.5 \%$. One of the main measures to reduce the energy losses in the transient acceleration modes is the reduction in the dynamic parameters, where the control conditions of the locomotive allow.

\subsubsection{Power Loss Transient Modes}

The analysis of the different speeds for the transient power loss modes has been performed at different power ranges, showing that the performance indicators are changing in the same way. In Figure 10, the power reduction mode from $830 \mathrm{~kW}$ to idle (at $\mathrm{n}=600 \mathrm{~min}^{-1}$ ) has been given. In the transient mode, two sections with different
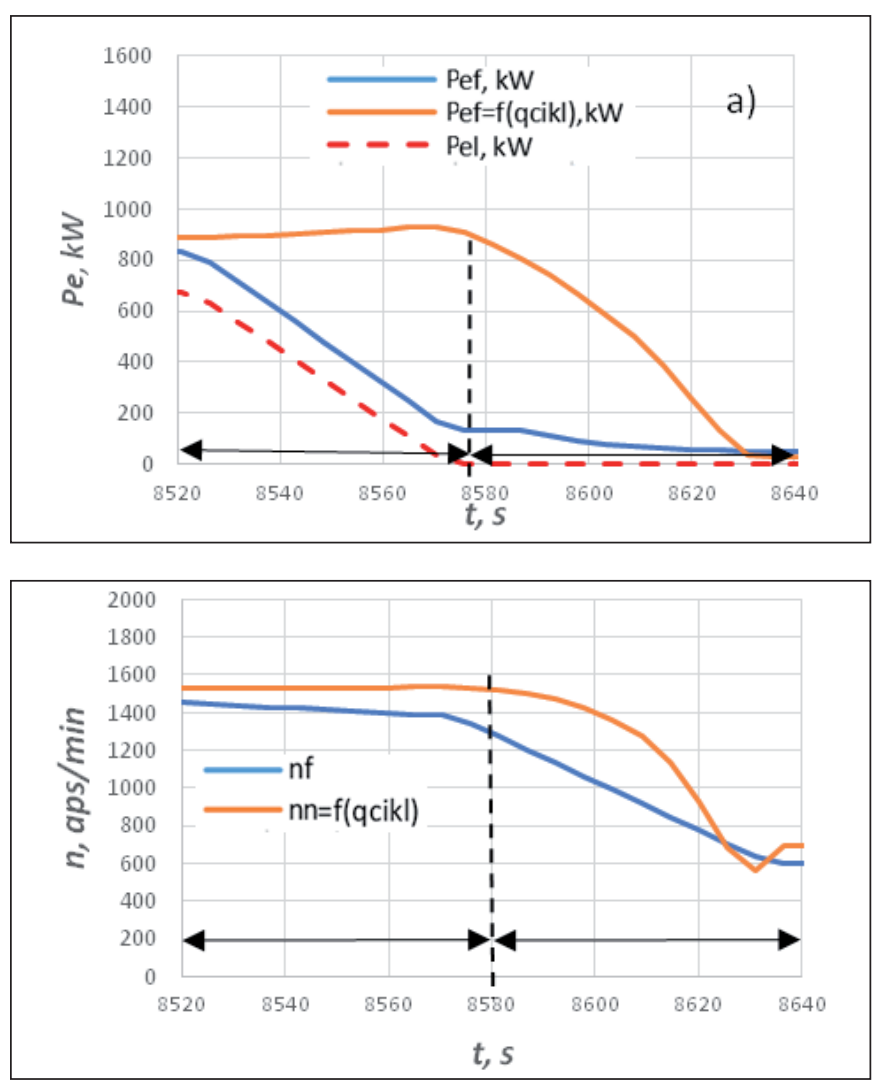

Fig. 10 Change in the CAT3512B-HD DE Energy Efficiency Parameters in the Process of Slow Acceleration 
dynamic parameters are distinguished: (i) speed of fastpower $\mathrm{P}_{\mathrm{e}}$ decrease from $630 \mathrm{~kW}$ to $170 \mathrm{~kW}$ section (8520 $\mathrm{s}-8570 \mathrm{~s}$ ) at $\mathrm{dP}_{\mathrm{ef}} / \mathrm{dt}=9.2 \mathrm{~kW} / \mathrm{s}$, and (ii)

slow $\mathrm{P}_{\text {ef }}$ decrease from $170 \mathrm{~kW}$ to close to idle speed $(20$ $\div 30 \mathrm{~kW}$ with auxiliary locomotive assemblies) at $\mathrm{dP}_{\text {ef }} / \mathrm{dt}$ $=2.9 \mathrm{~kW} / \mathrm{s}(8570 \mathrm{~s}-8630 \mathrm{~s})$. The $\mathrm{P}_{\text {ef }}$ and $\mathrm{n}_{\mathrm{f}}$ interfaces are characterized by the beginning of a different set of parameters: the decrease in $\mathrm{P}_{\mathrm{ef}}$ begins with a linear dependence from $t=8520 \mathrm{~s}$, whereas $n_{f}$ decrease starts only from 8570 $s$ when the first intensive segment of the $P_{\text {ef }}$ decrease is reached (see Fig. 11, a)). Because ECU engine speed $n_{f}$ is working to synchronize the position of the controller with the cyclic fuel portion, the decrease in $\mathrm{q}_{\mathrm{cycl}}$ also starts at $\mathrm{t}$ $=8570 \mathrm{~s}$. Thus, the power of the engine calculated by the actual $\mathrm{q}_{\text {cycl }}$ of the steady-state modes in $\mathrm{P}_{\text {en }}$ significantly differs. For example, at $\mathrm{t}=8570 \mathrm{~s}, \mathrm{P}_{\text {ef }}$ drops to $170 \mathrm{~kW}$ at the end of the first segment, and the $\mathrm{P}_{\mathrm{en}}$ drop only starts at $900 \mathrm{~kW}$. The difference is $730 \mathrm{~kW} . \mathrm{P}_{\text {en }}^{\mathrm{en}}$ and $\mathrm{P}_{\mathrm{ef}}$ are equal after the transient regime.

Such a $\mathrm{P}_{\text {ef }}$ and $\mathrm{q}_{\text {cycl }}$ imbalance in turn determines the effective reduction in efficiency $\eta_{\mathrm{ef}}$ (Fig. 11, b)). The decrease in the power leads to a decrease in $\eta_{e^{\prime}}$, but compared with the steady-state modes, the decrease in $\eta_{\mathrm{e}}$ in the transient mode is much more intense (see Fig. 11, c)). The indicator coefficient of the efficiency $\left(\eta_{i f}\right)$ does not change in the transient mode (Fig. 11b) because the optimum ratio of $\mathrm{q}_{\text {cycl }}$ with $\mathrm{P}_{\mathrm{k}}$ or $\alpha$ has been maintained (see Fig. $11 \mathrm{a}$ ).

The changes in the effective $\eta_{\text {ef }}$ and mechanical $\eta_{\mathrm{mf}}$ vary linearly from 0.41 to $0.08-0.1$ and from $0.80-0.81$ to $0.14-$ 0.15 . Because the $P_{\text {ef }}$ DE changes exclusively in the first mode section, in the second section, the values of $\eta_{m f}$ and $\eta_{\text {ef }}$ are practically unchanged (see Fig. $11 \mathrm{~b}$ ).

The objective of assessing the energy efficiency reserves in the transient power reduction mode (Fig. $11 \mathrm{c}$ ) is to provide the ratio of the actual efficiency coefficient and efficiency coefficient ratios corresponding to the steady-state regimes: during the reduction phase of the intense $P_{\text {ef }}$ and $\eta_{\text {ef }} / \eta_{\text {en }}$ decrease to $0.14 \div 0.15$, up to $85 \%$ of the heat dissipated from the fuel is no longer used to generate effective power. Because the $\eta_{\text {if }} / \eta_{\text {in }}$ regime is close to 1.0, the negative changes in $\eta_{\text {ef }}$ are determined by the corresponding decrease in the mechanical efficiency up to $0.14-0.15$ units.

In the second section, relative to the slow mode, (see Fig. $10 \mathrm{c}$ ) the efficiency coefficient ratios do not change until the end of the mode. Only when resetting to $8630 \mathrm{~s}$, they are reset to values close to 1.0 .

The loss of the potential energy efficiency, measured in terms of $\eta_{\mathrm{ef}} / \eta_{\mathrm{en}}$ for the entire transient operation, including, based on $\mathrm{G}_{\mathrm{f}}$ evaluation, is $10-14 \%$ on an average. However, a small part of this energy is not used for traction. In the power reduction mode, the energy is regenerated by the force of the electric motors for stopping the train. These energy losses can be reduced by the rational optimization of the parameters of ECU and the locomotive control systems, adapting them to the specific operational interface "freight line - train mass - train speed". For the realization, it is expedient to use the developed and approved methodology solutions for implementing them in the software.
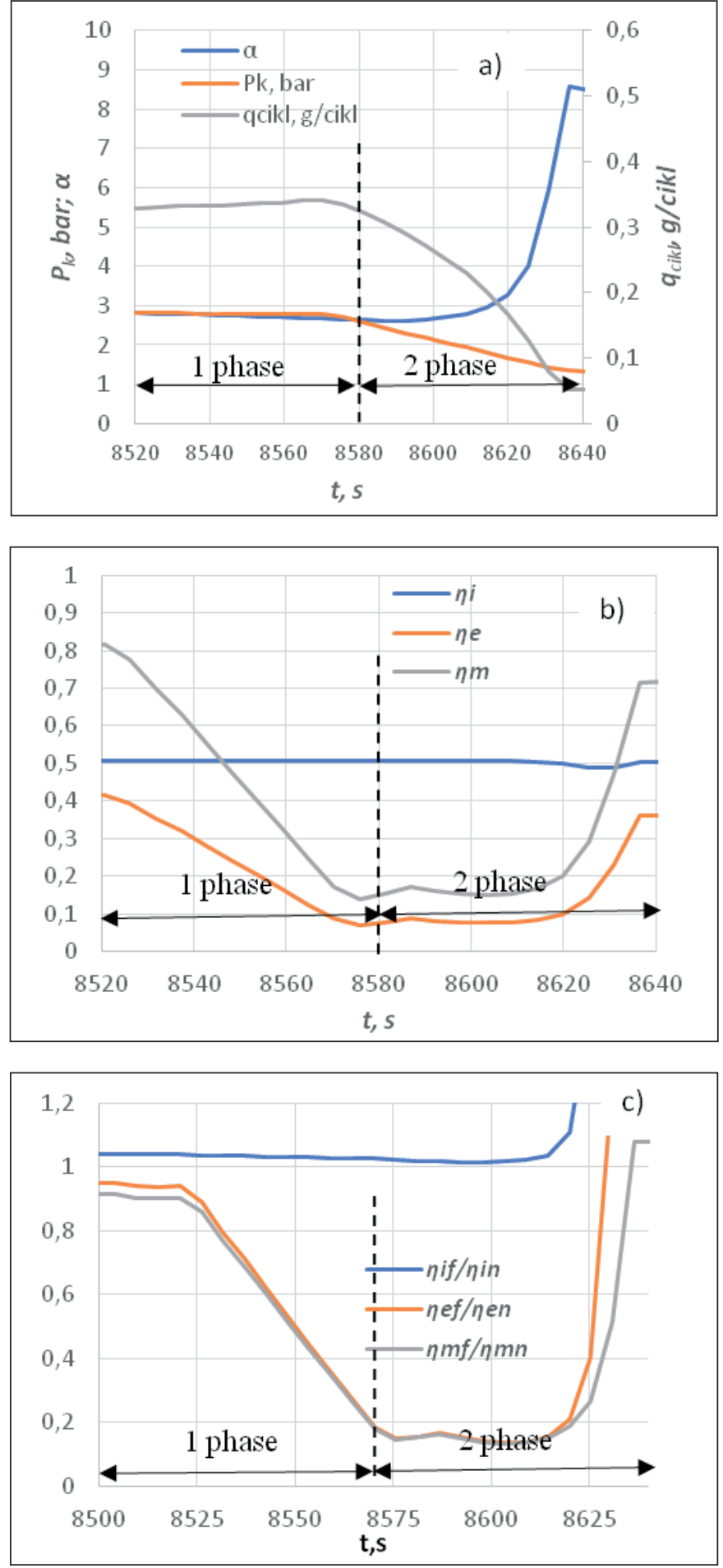

Fig. 11 Power Loss Transient Mode: a) $-\mathrm{P}_{\mathrm{k}^{\prime}} \alpha$ and $\mathrm{q}_{\mathrm{cyc}}$; $\mathrm{b}$ ) - Change in the Efficiency c) - Relative Efficiency.

\section{Conclusions}

1. Based on complex researches, the methodologies for the research and optimization during transient operating modes of heavy DEs and their realization by unifying the methodology have been developed:

- Performance characteristics from the ECU for continuously recording the data with an accuracy of $1.5-2.0 \%$. 
- Mathematical modelling of DE parameters in transient operation modes based on the use of a single-zone model and artificial neural networks method.

- Analytical solutions for the determination and evaluation of the DE energy efficiency parameters in the transient regimes, by means of which the analytical relations of the indicator efficiency from cycle parameters $\eta_{i}=f\left(\alpha, q_{c y c l}\right)$ have been derived.

2. An effective method for the mathematical modelling of the DE energy parameters has been developed and for the actual operation data, the unidirectional model of the AVL BOOST programme and ECU-enabled experimental statistical data processing artificial neural network (ANN) tool have been used. The efficiency of the method is confirmed by the errors not exceeding $5-8 \%$ as well as from the determination coefficient between the experiment and calculation results of $\mathrm{R}^{2}=0.97-0.99$.

3. Using the developed methodology, SC "Lietuvos Gelezinkeliai" has widely used reserves for the improvement of the energy efficiency parameters of the CAT3512B-HD series of commercial catalytic converters (under $\mathrm{q}_{\mathrm{cycl}}=$ idem):

- In the boom mode, the DE effect of $\eta_{e}$ deteriorates compared with the established modes to $12 \%$. The main reason for the reduction of DE $\eta_{e}$ and parallel fuel overflow is the additional loss of the kinetic energy of the moving diesel generator and nodes, which in the whole range of operation reaches 3-3.5\%.

- Power reduction in the transition mode DE energy efficiency indicators decreases for a short time by up to $85 \%$ and, on an average, by $10-14 \%$ : the energy losses relate to the features of the control of the ECU system, during which the DE has produced energy is regenerated for the dynamic braking of the powertrain by the electric motors. These energy losses can be reduced by optimizing the ECU and locomotive control system parameters adapted to the specific operating conditions "freight line - train weight - train speed".

\section{Acknowledgements}

The results of the research, described in the article, have been obtained by using the virtual internal engine simulation tool AVL BOOST, acquired by signing the Cooperation Agreement between AVL Advanced Simulation Technologies and Faculty of Transport Engineering of Vilnius Gediminas Technical University.

The authors express gratitude to SC "Lietuvos geležinekliai" for providing the opportunity to cooperate and have access to their infrastructure and data that were necessary for the research. We hope to continue our cooperation in the future.

\section{References}

[1] AVL BOOST USER GUIDE v2011, Graz: AVL LIST GmbH, 2011.
[2] Babeł M, Szkoda M. Diesel locomotive efficiency and reliability improvement as a result of power unit load control system modernisation. Eksploatacja i Niezawodnosc Maintenance and Reliability 2016; 18(1): 38-49.

[3] Bosch R. Diesel-Engine Management 4th edition, Wiley 4 edition, 2006.

[4] Caterpillar. Operation and maintenance manual 3500B and 3500 Engines with EUI option, 1999, https://issuu.com/ ahmadfikrywork/docs/caterpillaroperationandmaintenancem (Accessed 12 September 2017)

[5] Challen B, Baranescu R. Diesel Engine Reference Book. Butterworth-Heinemann Ltd; 2 edition, 1999.

[6] Djachenko V G. Teorija dvigatelej vnutrennego sgoranija. Ucebnik. Harkov: HNADU, 2009.

[7] Giakoumis E G, Alafouzos A I. Comparative study of turbocharged diesel engine emissions during three different Transient Cycles. International journal of energy research 2010; 34: 1002-1015.

[8] Grabowski L, Pietrykowski K, Wendeker M. AVL Simulation Tools Practical Applications, Graz - Lublin: Politechnika Lubelska, 2012.

[9] Hansson P A, Lindgren M, Nordin M, Pettersson O A. Methodology for measuring the effects of transient loads on the fuel efficiency of agricultural tractors. Applied Engineering in Agriculture 2003; 19(3): 251-257.

[10] Heywood J B. Internal combustion engine fundamentals, McGraw-Hill, 1988.

[11] Hromádko J, Hönig V, Miler P. Applications of NRTC cycle to determine a different fuel consumption and harmful emissions caused by changes of engine's technical conditions, Maintenance and Reliability. 2008; 4: 63-65.

[12] Ivanchenko N N. Vysokij nadduv dizelej, Mašinostroenie, Leningr. otd-nie, 198, 1983.

[13] Jamrozik A. The effect of the alcohol content in the fuel mixture on the performance and emissions of a direct injection diesel engine fueled with diesel-methanol and diesel-ethanol blends. Energy Conversion and Management, 2017; 148: 461-476.

[14] Kruggel 0. Progress in the combustion technology of high performance diesel engines toward reduction of exhaust emissions without reduction of operation economy. BadenWurttemberg Thechnology Conference, Oslo, 1989; 14.

[15] Kruggel 0. Undersuchungen zur Stickoxidminderung an schnellaufenden Gro diesel - motoren, MTZ: Motortechn Bd; 1988; 22-29.

[16] Lebedev S V. Inzhenernaja metodika kompleksnoj raschetnoj optimizacii parametrov forsirovannyh vysokooborotnyh dizelej. Dvigatelestroenie 1998; 3: 5-12.

[17] Lebedev S V, Nechaev L V. Sovershenstvovanie pokazatelej vysokooborotnyh dizelej unificirovannogo tiporazmera. Akademija transporta 1999; 112.

[18] Lebedev S V, Rodin A F. Modelirovanie harakteristiki teplovydelenija dizelej ChN16,5/15,5 i ChN16,5/18,5. Dvigatelestroenie 1998; 4: 18-21.

[19] Lebedevas S, Dailydka S, Jastremskas V, Vaičiūnas G. Research of the rational operational load of diesel locomotives. Eksploatacja i Niezawodnosc - Maintenance and Reliability 2014; 16 (4): 545-553.

[20] Lebedevas S, Dailydka S, Jastremskas V, Rapalis P. The influence of locomotive diesel engine transient operating modes on energy usage. Transportation Research Part D: Transport and Environment 2015; 34: 219-229. 
[21] Lebedevas S, Dailydka S, Jastremskas V, Rapalis P. Research of energy efficiency and reduction of environmental pollution in freight rail transportation. Transport 2016; 32(3): 291-301.

[22] Lee H D, Park S J, Ryu R M, Parkd J H. Development of a highly efficient low-emission diesel engine-powered co-generation system and its optimization using Taguchi method. Applied Thermal Engineering 2013; 50(1): 491-495.

[23] Lindgren M, Hansson P A. Effects of Transient Conditions on Exhaust Emissions from two Non-road Diesel Engines. Biosystems Engineering 2004; 87(1): 57-66.

[24] Lingaitis L P, Lebedevas S, Liudvinavičius L. Evaluation of the operational reliability and forecasting of the operating life of the power train of the freight diesel locomotive fleet. Eksploatacja i Niezawodnosc - Maintenance and Reliability 2014; 16 (1): 73-79.

[25] Makowicki T, Bitzer M, Grodde S, Graichen K. Cycle-by-Cycle Optimization of the Combustion during Transient Engine Operation. IFAC-Papers On Line, 2017; 50(1): 11046-11051.

[26] Maroteaux F, Saad C. Combined mean value engine model and crank angle resolved in-cylinder modelling with NOx emissions model for real-time Diesel engine simulations at high engine speed. Energy 2015; 88: 515-527.

[27] Merker G, Schwarz C, Stiesch G, Otto F. Simulating combustion: simulation of combustion and pollutant formation for engine development. Springer Berlin Heidelberg, 2006.

[28] Mollenhauer K, Tschoeke H. Handbook of Diesel Engines, Springer Heidelberg Dordrecht London New York, 2010

[29] Nabi N, Zare A, Hossain F M, Bodisco T A, Ristovski Z D, Brown R J. A parametric study on engine performance and emissions with neat diesel and diesel-butanol blends in the 13-Mode European Stationary Cycle. Energy Conversion and Management 2017; 148: 251-259.

[30] Nikzadfar K, Shamekhi A H. Investigating the relative contribution of operational parameters on performance and emissions of a common-rail diesel engine using neural network. Fuel 2014; 125: 116-128.

[31] Nüescha T, Wanga M, Isenegger P, Onder C H, Steiner R, Macri-Lassus P, Guzzellaa L. Optimal energy management for a diesel hybrid electric vehicle considering transient PM and quasi-static NOx emissions. Control Engineering Practice 2014; 29: 266-276.

[32] Orlin A S, Virubov D N, Ivin V I, Kruglov M G, Leonov O B, Mizerinjok G N. Teorija rabočih procesov porševih dvigatelej. Mašinostrojenije, 1971.
[33] Portnov D A. Bystrohodnye turboporšnevye dvigateli s vosplameneniem ot sžatija. Mašinostroenie 638, 1963.

[34] Rakopoulos C D, Dimaratos A M, Giakoumis E G, Rakopoulos D C. Evaluation of the effect of engine, load and turbocharger parameters on transient emissions of diesel engine, Energy Conversion and Management, 2009; 50: 2381-2393.

[35] Rakopoulos C D, Giakoumis E G, Hountalas D T. Experimental and simulation analysis of the transient operation of a turbocharged multi - cylinder IDI diesel engine, International journal of energy research, 1998; vol 22: 317-331.

[36] Rakopoulos C D, Giakoumis E G. Diesel engine transient operation principles of operation and simulation analysis. Springer. 2009.

[37] Rakopoulos C D, Giakoumis E G. Availability analysis of a turbocharged diesel engine operating under transient load conditions. Energy, 2004; Vol. 29: 1085-1104.

[38] Rapalis P, Lebedeva G, Lebedevas S. Heavy Transport Diesel Engine Operational Energy Parameter Mathematical Modelling Research, Procedia Engineering, 2016; Volume 134; p. 371-376.

[39] Semenov B N, Ivanchenko N N. Zadači povyšenija toplivnoj èkonomičnosti dizelej i puti ih rešenija, Dvigatelestroenie 1990; 11: 3-7.

[40] Theotokatos G P. Ship Propulsion Plant Transient Response Investigation using a Mean Value Engine Model. International Journal of Energy 2008; 4(2): 66-74.

[41] Tolstov A I. Indikatornyj period zapazdyvanija vosplamenenija i dinamika cikla bystrohodnogo dvigatelja s vosplameneniem ot sžatija, Issledovanie rabočego processa i podači topliva $\mathrm{v}$ bystrohodnyh dizeljah. Trudy NILD 1955; 1: 5-55.

[42] Tutaka W, Lukács K, Szwaja S, Bereczky A. Alcohol-diesel fuel combustion in the compression ignition engine, Fuel, 2015; 154(15): 196-206.

[43] Vibe I I. Novoe o rabočem cikle dvigatelej, 1962.

[44] Wei M, Li S, Xiao H, Guo G, Key H. Combustion performance and pollutant emissions analysis using diesel/gasoline/isobutanol blends in a diesel engine. Energy Conversion and Management 2017; 149: 381-391.

[45] Woschni G J. Die Berechnung der Wandverluste und der Thermischen Belastung der Bauteile von Dieselmotoren. Motortechnishe Zeitschrift 1970; 30(12): 491-499

[46] Yum K K, Taskar B, Pedersen E, Steen S. Simulation of a twostroke diesel engine for propulsion in waves. International Journal of Naval Architecture and Ocean Engineering 2017; 9(4): 351-372. 